\title{
Microbiology Teaching Development in Nutrition Material, Growth and Metabolism of Microbial Based on Community Technology Science (STM) for Students of Biology of Padang State University
}

\author{
Nita Ella Demelia ${ }^{1 *}$ Dwi Hilda Putri ${ }^{2}$ \\ ${ }^{1}$ Student of Master Program Biology Department, Math and Natural Science Faculty, Universitas Negeri Padang, \\ Padang, Indonesia \\ ${ }^{2}$ Biology Department, Math and Natural Science Faculty, Universitas Negeri Padang, Padang, Indonesia \\ *Corresponding author. nitaellademelia@gmail.com
}

\begin{abstract}
Initial investigations obtained reference data used by students so far have been taken from microbiology books with a long publication year. Based on the results of the questionnaire, the students felt the benefits of studying microbiology in daily life, but the student references did not support because there was no renewal of science in the references used. This type of research was a development research using the Plomp model. The development phase of the Plomp model consisted of initial investigation, prototype development and assessment. The instruments used were validation assessment sheets, practicality assessment sheets by lecturers and students, observation sheets used by observers to assess attitude competencies, and essay questions to assess student knowledge competencies. The results showed that the Community Science Technology (STM)-based microbiology textbook on nutrition, growth and microbial metabolism materials for students was very valid based on expert assessments in the didactic, construct, and technical fields. Students and lecturers categorize the Community Technology Science (STM)-based microbiology textbook on nutrition, growth, and microbial metabolism materials wasin the very practical category because of their ease of use. This Community Technology Science (STM)-based microbiology textbook on nutrition, growth and microbial metabolism materials was categorized as effective on knowledge competence. Based on the values obtained, it was concluded that the Community Technology Science (STM)-based microbiology textbook on nutrition, growth and microbial metabolism materials on biology students at UniversitasNegeri Padang was valid, practical and effective.
\end{abstract}

Keywords: Textbook, Microbiology, Community Technology Science.

\section{INTRODUCTION}

Education is a very important thing in life aimed at educating people. Higher education is an institution in education that is expected to produce graduates who have scientific academic ability and are able to apply it in their lives. The curriculum in tertiary institutions is regulated and adjusted for each study program by the equalization of the Indonesian National Qualification Framework (KKNI). KKNI according to Presidential Regulation No. 8 of 2012 is a competency qualification framework that can equalize in the field of education. The equalization of the field in the IQF can be achieved with the achievement of qualified learning for a certain level of education. Learning achievement in tertiary level is equivalent to level 6 . In KKNI parameters have been determined learning outcomes where in general the ability to work for level 6 is set to be able to apply, study, design, utilize IPTEKS and solve problems in accordance with their fields [1].
Achievement of the IQF is needed as a process of developing important components to improve knowledge and skills competence [2]. Improving knowledge competency can be achieved with the learning process. Group-based learning has been proven to improve student learning [3] and assignments can also affect student skills [4].

The target of learning achievement in KKNI must go well; one of them is with the lecture process. Education in higher education has compulsory subjects and elective courses. One of the compulsory subjects in the Biology FMIPA UNP department is microbiology. Microbiology is a branch of biology that studies microorganisms. Microorganisms are very small living things that can only be seen with a microscope including bacteria, viruses, and fungi. The field of microbiology studies is one of the fields of study that is important to understand and master because microorganisms have an important role in human life, both beneficial and detrimental. 
Based on interviews, it is known that there are still many students who have difficulty understanding the concepts and principles of microbiology. Difficulties of students are seen during the biotechnology lecture process and other optional lectures. To achieve the learning objectives in the course, lecturers often have to repeat discussing several microbiology topics so that students can connect with the material to be studied.

The results of the interview also revealed that microbiology lectures used the lecture method and group discussions with students making papers and PPT according to the material. Making papers and PPT is recommended to use references in the form of text books and journals, but generally students use more references from the internet (web / blog) that have not been validated. The results of UNP and UNAND Biology student questionnaires regarding the use of references in microbiology lectures revealed that the references used were not in accordance with the topic and did not include indicators of learning outcomes and the references used did not have any renewed knowledge because they were obtained from books with a long publication year.

Based on a questionnaire given to 72 Biology students, it is known that the topic of microbial nutrition (52\%), microbial growth $(54 \%)$ and microbial metabolism $(56 \%)$ are topics that are difficult for students to master because of the large amount of material and difficult concepts to understand. Maximizing the learning process requires teaching materials that can support students in understanding concepts well, thinking critically and being able to apply them in daily life.

Teaching material that enables students to reach concept understanding well is textbooks. Textbooks have an important role in the learning process. Educators are required to be able to compile textbooks that are interesting, innovative, contextual and in accordance with the needs of students. The textbook used can improve student learning outcomes [5]. Textbooks can also trigger students to improve their intellectual abilities in learning [6]. The use of textbooks can facilitate and facilitate the delivery of material to students [7]. Microbiology textbooks that can provide concept understanding are textbooks using the community technology science (STM) approach. STM aims to improve learning achievement and can broaden students' insights [8]. STM is in line with the theory of cognition that defines learning as knowledge and skills gained from everyday life [9] can be seen from the characteristics of STM with the active involvement of students in obtaining information to solve problems in everyday life [10].

Community Technology Science(STM) textbooks can improve student learning competencies. The use of community technology science models (STM) can improve critical thinking skills, the ability to apply concepts in everyday life and higher order thinking skills [11]. Based on the problem, a research on the development of the Community Technology Science-based (STM) microbiology textbook on nutrition, growth and microbial metabolism materials for Biology students of Universitas Negeri Padang was conducted.

\section{METHODS}

\subsection{Initial Investigation Stage}

The initial investigation stage aims to find out the problems faced by students in microbiology lectures. The activities at this stage were in the form of observation, analytical gathering and defining the problems that occurred in the learning process. The initial investigation stage started with analyzing the problems and needs of students, microbiology syllabus analysis, and microbiology text analysis.

\subsection{Initial Investigation Stage}

This stage began after the initial investigation stagewas completed. This stage consisted of microscopes that helped in developing and improving products. This stage consisted of several stages of making a prototype as follows.

a. Development of Prototype I

The results of the prototype design in the initial stages were called prototype I. The initial design was done by researchers based on the results of preliminary research that has been done.

b. Development of Prototype II

Prototype II was the stage of development by conducting a self-evaluation using a checklist. Self-evaluation (selfevaluation) was by revising the textbook itself that has been designed. The evaluation method itself was carried out aimed at reviewing important components in the microbiology textbook.

c. Development of Prototype III

Prototype III was then validated with one-on-one expert review and evaluation. The validation with expert review was carried out based on expert judgment (validator) from the didactic, construct, and technical aspects. This evaluation was carried out using an expert validation sheet. The validity data was obtained by analyzing the validation questionnaire that has been filled out by the validator. The analysis was carried out with the following steps. 1) Give a score of answers to each indicator with criteria based on scale 1-4.

2) All items given a score are then tabulated and the percentage is searched using the following formula.

3) Determination of the validity result with the following criteria

Validity $=\frac{\text { score obtained }}{\text { score maximum }} \times 100 \%$

4) Determination of the validity result with the following criteria. 
Table 1. Module Validity Criteria

\begin{tabular}{ll}
\hline $\begin{array}{l}\text { Validity } \\
(\%)\end{array}$ & Category \\
\hline $81-100$ & Very Valid \\
$61-80$ & Valid \\
$41-60$ & Quite Valid \\
$21-40$ & LessValid \\
$0-20$ & Invalid \\
\hline
\end{tabular}

At the same time one-on-one evaluations were carried out on three biology students using interview guide sheets.

d. Development of Prototype IV

Prototype III was evaluated through small group evaluation. At this stage an evaluation of six biology students at the Faculty of Mathematics and Natural Sciences, UNP was low, medium, and high ability, each consisting of two members. This formative evaluation used a student practice questionnaire sheet. The results of the revised Prototype III were called Prototype IV.

\subsection{The Assessment Stage}

a. Practicality Instruments

Field tests or large group trials (field tests) were conducted to see the practicality of microbiology textbook that have been designed. Practicality is the level of practicality of textbooks when used in the learning process. Practicality is carried out by lecturers and students who have used STMbased microbiology textbooks that were developed. The research data obtained were analyzed by qualitative and quantitative analysis. The data on the practicality of using microbiology textbook on microbial nutrition material, microbial growth and microbial metabolism were analyzed by percentage (\%), using the following formula.

Practicality $=\frac{\text { score obtained }}{\text { skor maksimum }} \times 100 \%$

After the percentage was obtained, grouping was done according to the following criteria.

Table 2. Criteria for Practicality of Textbook

\begin{tabular}{ll}
\hline Validity (\%) & Category \\
\hline $81-100$ & Very Practical \\
$61-80$ & Practical \\
$41-60$ & Quite Practical
\end{tabular}

After the percentage was obtained, grouping was done according to the following criteria.

b. Instrument of Effectiveness

Effectiveness instruments were used to collect effectiveness data using student knowledge competency tests. The effectiveness instrument was used to determine the percentage of students' success after attending the class using the STM-based microbiology textbook on microbial nutrition, microbial growth and microbial metabolism. Knowledge Competency Assessment was done by giving a written test in the form of an essay test used to determine student learning outcomes. The student test results were calculated based on individual completeness and the average grade obtained by students. The criteria used by UNP which stated that they pass if the quality obtained was B- to A. The percentages obtained were grouped according to the following criteria.

Table 3. Grade of Value

\begin{tabular}{lll}
\hline No & The Number Value & The Letter Value \\
\hline $\mathbf{1}$ & $85-100$ & $\mathrm{~A}$ \\
\hline $\mathbf{2}$ & $80-84$ & $\mathrm{~A}-$ \\
\hline $\mathbf{3}$ & $75-79$ & $\mathrm{~B}+$ \\
\hline $\mathbf{4}$ & $70-74$ & $\mathrm{~B}$ \\
\hline $\mathbf{5}$ & $65-69$ & $\mathrm{~B}-$ \\
\hline $\mathbf{6}$ & $60-64$ & $\mathrm{C}+$ \\
\hline $\mathbf{7}$ & $55-59$ & $\mathrm{C}$ \\
\hline $\mathbf{8}$ & $50-54$ & $\mathrm{C}-$ \\
\hline $\mathbf{9}$ & $40-49$ & $\mathrm{D}$ \\
\hline $\mathbf{1 0}$ & $0-39$ & $\mathrm{E}$ \\
\hline
\end{tabular}

\section{RESULT AND DISCUSSION}

\subsection{Result}

a. Preliminary Investigation Results

The initial investigation phase aims at finding out the problems faced by students in microbiology lectures. The activities at this stage took the form of observation, questionnaire data collection and defining the problems that occurred in the lecture process. The results of research conducted by Demelia and Nita (2019) [14] revealed that first, microbiology lectures were not yet optimal in terms of learning outcomes not yet achieved. Second, the microbiology textbook used by students was not enough to understand the material and its application in daily life. Third, the unavailability of microbiology textbook enhanced an understanding of concepts and newness of science. Fourth, the presentation of material in the microbiology textbook has not yet integrated community technology science (STM).

b. Results of Development or Prototyping Stage This research started from the design and manufacture of microbiology textbook products on microbial nutrition, microbial growth, and microbial metabolism materials community technology science (STM). The STM steps in the microbiology textbook developed aims at enabling students to apply the material to their daily lives. Microbiology textbook were designed according to STM stages according to Poedjiadi: introduction: initiation / apperception / exploration, concept development, application of concepts in life, stabilization of concepts, and assessment [8]. Lectures using the community technology science-based microbiology textbook aims at improving knowledge competence, training students' process skills, improving applications in daily life, so the students find learning useful to themselves, fostering 
creative thinking and training students to solve problems in everyday life [8] When students were invited to be more active and given issues related to daily life through the learning process, good results were obtained [16]. Learning is the interaction of students with the environment to achieve goals [32]. Learning using skills involves students with problems found in everyday life to make the learning process better [17]. The principles in STM showed personal and social views related to society and problems that occured in the community [18].

The Microbiology textbook on microbial nutrition, microbial growth and microbial metabolism materials were created using the 2007 Microsoft Office Publisher application. The components in the community technology science-based microbiology textbook were the textbook cover, preface, table of contents, list of images, list of tables, concept maps, the steps in science and technology society, bibliography, and author biography. The design results at this stage were called prototype I.

The results of prototype I were followed by selfevaluation. In this activity a review of the important components of the microbiology textbook developed has been made using a checklist. This stage was revised to some writing errors and additions. The results of the revised prototype I were called prototype II.

Prototype II was then carried out by expert review and one to one evaluation. The expert evaluation activities carried out by looking at the validity of the microbiology textbook on microbiological nutrition, microbial growth and microbial metabolism materials based on validator assessment which included three aspects: didactic, construct and technical. Based on the assessment given by the validator, it can be seen that the validity of microbiology textbook on microbial nutrition material, microbial growth and microbial metabolism for every aspect is in the very valid category. The results of the validity of microbiology textbooks can be seen in Table 4 .

Table 4

\begin{tabular}{lll}
\hline The Validated & Validity $(\boldsymbol{\%})$ & Criteria \\
Aspects & & \\
\hline Didactic & 88,8 & Very Valid \\
Construct & 89,16 & Very Valid \\
Technique & 84,16 & Very Valid \\
Total & $\mathbf{8 7 , 3 7}$ & Very Valid \\
\hline
\end{tabular}

Furthermore, a one-to-one evaluation was conducted to obtain input from the student's perspective on the microbiology textbook developed. One-on-one evaluations were carried out on 3 students with high, medium and low level academic abilities. The revised results of prototype II were called prototype III.

Prototype III developed was evaluated by a small group to get improvements and an evaluation of the practicality of microbiology textbook. The number of students in a small group test was six students with academic abilities varying from high, medium, and low. The varied student abilities were intended so that responses and suggestions given by students represented the sample population. The small group evaluation results provided information that the microbiology textbook produced were already in the practical category for use with a percentage of $80.00 \%$. The revised results of prototype III were called prototype IV.

\section{c. Assessment Stage}

Prototype IV was then subjected to field tests on Biology FMIPA UNP students and two microbiology lecturers. The field test aims at seeing the practicality of using the STMbased microbiology textbook on microbial nutrition, microbial growth and microbial metabolism materials developed. The results of practicality tests by students can be seen in Table 5 and microbiology lecturers in Table 6 .

Table 5. Results of Analysis of Practicality of STM-Based Microbiology Textbook on Nutrition, Growth, and Metabolism of Microbial Materials filled

in by Students

\begin{tabular}{llll}
\hline No & Aspect & $\begin{array}{l}\text { Score } \\
(\mathbf{\%})\end{array}$ & Category \\
\hline $\mathbf{1}$ & Easily use & 81 & Very Practical \\
\hline $\mathbf{2}$ & Time & 79,1 & Practical \\
\hline $\mathbf{3}$ & Easily interpret & 78,4 & Practical \\
\hline $\mathbf{4}$ & $\begin{array}{l}\text { Having } \\
\text { Equivalent }\end{array}$ & 79 & Practical \\
\hline Mean & 80 & Practical \\
\hline
\end{tabular}

Based on Table 5 it was known that the mean of the practicality assessment by the students was $80.00 \%$ with practical criteria. This showed that STM-based microbiology textbooks on microbial nutrition, microbial growth and microbial metabolism practically were used by students in the microbiology lecture process.

Based on Table 6 it was known that the average practicality assessment by microbiology lecturers was $87.45 \%$ with very practical criteria. This showed that STM-based microbiology textbook on microbial nutrition, microbial growth and microbial metabolism were very practical to be used by lecturers in microbiology lectures.

Table 6. Results of The Data Analysis of Practicality of the STM-Based Microbiology Textbook on Microbial Nutrition, Microbial Growth, and Microbial Metabolism Materials filled by Lecturers

\begin{tabular}{llll}
\hline No & Aspect & Score(\%) & Category \\
\hline $\mathbf{1}$ & Easily use & 88,8 & $\begin{array}{l}\text { Very } \\
\text { Practical }\end{array}$ \\
\hline $\mathbf{2}$ & Time & 100 & $\begin{array}{l}\text { Very } \\
\text { Practical }\end{array}$ \\
\hline $\mathbf{3}$ & Easily interpret & 81,25 & $\begin{array}{l}\text { Very } \\
\text { Practical }\end{array}$ \\
\hline $\mathbf{4}$ & Having Equivalent & 81,25 & $\begin{array}{l}\text { Very } \\
\text { Practical }\end{array}$ \\
\hline Mean of Practicality (\%) & 87,45 & $\begin{array}{l}\text { Very } \\
\text { Practical }\end{array}$ \\
\hline
\end{tabular}


d. The Effectiveness Test of Knowledge Competence The results of the effectiveness test were used as a guideline in knowing the effectiveness of the products developed in the form of the STM based microbiology textbook on nutrition, growth and metabolism of microbes. The data obtained from written tests in the form of essay questions given to students on midterm exams. The knowledge competency results of the student midterm can be seen in Figure 1.

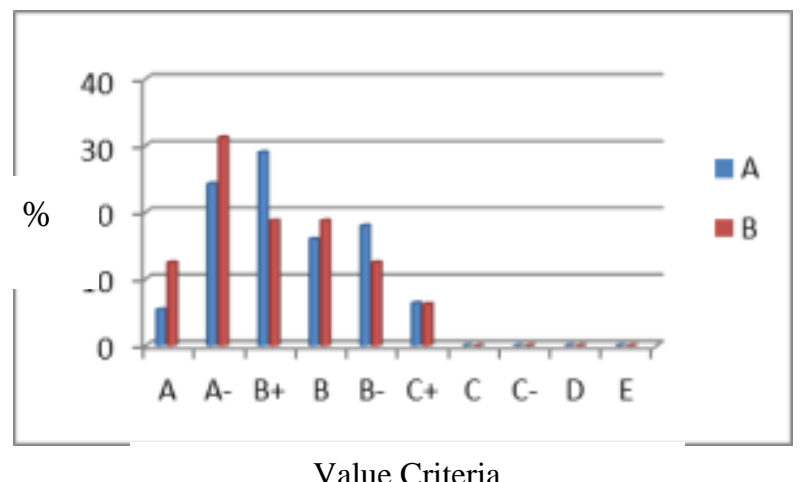

Figure 1

Based on Figure 1 it was known that $93.21 \%$ of students have passed on the topic of microbial nutrition, growth and metabolism (grades in the category B- to A) and $6.79 \%$ of students were not graduated because they did not meet the completeness criteria. The results of the knowledge competency assessment were known that the STM-based microbiology textbook on nutrition, growth and microbial metabolism was effective to help students achieve the desired competencies.

\subsection{Discussion}

This research resulted in a product in the form of the STMbased microbiology textbook on nutrition, growth and microbial metabolism. The Microbiology textbook was developed using varied letters such as the Maiandra $G D$ font. This is appropriate with the questionnaire for the needs of students who want microbiology textbooks using varying letters. Maiandra $G D$ typeface is formal, simple but easy to read so it is suitable to use in textbooks [19]. The microbiology textbook templates used are dominated by blue and black. The blue color gives an atmosphere of calm, strength and truth [20].

The validation of the STM-based microbiology textbook on nutrition, growth and microbial metabolism materials was carried out by three validators. The analysis of the data from the validity assessment sheet of this textbook is in terms of didactic, construct, and technical aspects. Sugiyono [21] stated that validation is the degree of accuracy between the data that occurs in the research object with the actual data. The results of the textbook validation data analysis showed that the STM-based microbiology textbook on microbial nutrition, growth, and metabolism materials had a validity score of $87.37 \%$ with very valid criteria.

The didactic aspects of the STM-based microbiology textbook were declared valid by the validator with a result of $88.80 \%$ with very valid criteria. From these criteria it can be seen that the microbiology textbook developed has been appropriate with the syllabus and learning outcomes. The validation refers to the accuracy, significance, and usefulness of a research conclusion [22].

The construct aspect was valid with a result of $89.16 \%$ with very valid criteria. Based on this it was concluded that STM-based microbiology textbook already used language that was easily understood by the students, the language that was appropriate with Indonesian language rules, and have clear sentences.

The technical aspects was valid by the validator with a validity of $84.16 \%$ with very valid criteria. Based on this it was concluded that all components of the technical aspects of the microbiology textbook which included writing, drawing, and graphic were fulfilled properly. The presentation of drawings is needed to support and clarify the material and increase the attractiveness of students [23]. The terms of technical aspects relating to writing, drawing, and appearance are in making microbiology textbooks [24].

The three aspects of evaluating the validation of microbiology textbooks are a unified whole and mutual support to develop good textbooks according to the rules. If a data generated from a product is valid, it can be said that the product developed has provided a description of the development objectives correctly and in accordance with the actual situation [25].

One valid one microbiology textbook according to the expert was evaluated. Based on one to one evaluation, it was found that STM based microbiology textbooks had good appearance, writing, pictures, and grammar. Then, a Small Group Evaluation was carried out through a practicality questionnaire given to six students who aimed to see the practicality of STM-based microbiology textbook before conducting a field test. The results of the small group practicality received a practical category with a result of $80.00 \%$. Textbooks said to be practical can be seen from the implementation time which should be short, fast, and precise [26].

Large group practicality test was conducted by students and microbiology lecturers with a mean of practicality of $80.00 \%$ by students and $87.45 \%$ by lecturers in very practical categories. Based on the results of the field test the STM-based microbiology textbook that was developed provides convenience in terms of its use. This is because the STM-based microbiology textbook developed was written with writing that is easy to read, a complete description of the material and helps understanding concepts, equipped with clear images, and the renewal of knowledge. STM-based microbiology textbooks also have advantages as an important factor in self-identification as a society [26].

The effectiveness competency test was conducted to determine the results of the use of the STM-based microbiology textbook on nutrition, growth and 
metabolism on lectures. Lectures require an approach that pays attention to curriculum and assessment [35]. Lectures are adult learning that is monotoritarian and self-directed [33]. Student learning assessment is an important thing in shaping student motivation and academic performance [28] and looking at student learning outcomes [34]. Lecturers must fully understand the competencies of students [29]. Assessment of knowledge competency tests can be done by means of written tests [30]. The effectiveness test of knowledge competency is assessed through written tests in the form of essays [24].

The use of STM-based microbiology textbook has a positive effect on the students' knowledge competence.

\section{CONCLUSION}

Based on the research that has been carried out, it has been concluded that the community technology science (STM)based microbiology textbook has been produced on the materials of nutrition, growth and metabolism for Biology students of UniversitasNegeri Padang, which are valid, practical and effective.

\section{REFERENCES}

[1] Peraturan Presiden Republik Indonesia Nomor 8 tahun 2012 Tentang Kerangka Kulaifikasi Nasional Indonesia.

[2] Loveys, Beth R., Brent N. Kaiser, Glenn McDonald, Olena Kravchuk, Matthew Giliham Steve Tyermen dan Amanda J. Able. 2014. The Development of Student Research Skills in Second Year Plant Biology. International Journal of Innovation in Science and in Athematics Education, 22 (3), 15-25.

[3] Pan, W., dan Allison, J. 2010. Exploring Project Based and Problem Based Learing in Environmental Building Education by in Integrated Critical Thinking. International Journal of Engineering Education, 26 (3), 547553.

[4] Webb, N. M. 2009. The Teacher's Role in Promoting Collaborative Dialogue in The Cllasroom. British Journal of Educational Psychology, 79, 1-28.

[5] Ginting, R.U. 2012. Efektivitas Penggunaan Buku ajar dan Belajar Mandiri dalam Rangka Peningkatan Hasil Belajar Termodinamika Dasar. Jurnal Pendidikan Teknologi dan Kejuruan Fakultas Teknik Unimed, 14 (1), 1-7.

[6] Onasanya, S. A dan E. O. Omosewo. 2011. Effect of Improvised and Standard Instructional Materials on Secondary School Students' Academic Performance in Physics in Ilorin Nigeria. Singapore Journal of Scientific Research, 1 (1), 68-76.

[7] Al Azri, Rashid hamed dan Majid Hilal Al Rashdi. 2014. The Effect of Using Authentic
This is because STM-based microbiology textbook contain STM stages so they can hone students' abilities. Learning using STM can provide students the opportunity to increase student activity in lectures [31]. Learning using STM has five stages: apperception, concept development, application of concepts, stabilization of concepts, and evaluation. From the results of knowledge competence showed that microbiology textbooks on nutrition, microbial growth and metabolism materials are effectively used by students because they can help students develop thinking skills, problem solving skills, and understand the material well.

Materials in Teaching. International Journal of Scientific \& Technology Research, 3 (10), 249254.

[8] Poedjiadi, Anna. 2005. Sains Teknologi Masyarakat. Bandung: PT Remaja Rosdakarya.

[9] Kok, L., dan Rika, V. 2014. A Science Technology Society Approach To Teacher Education for the Foundation Phase: Students' Empiricist Views. South African Journal of Childhood Education, 4 (1), 95-110.

[10] Akcay, H., dan Yager, R. E. 2010. The Impact of a Science Technology Society Teaching Approach on Student Learning in Five Domains. Journal of Science Education and Technology, 19 (6), 602-611.

[11] Arbi, Yulisa Rizki. 2017. Pengembangan Modul Berorientasi Sains Teknologi Masyarakat Dilengkapi Asesmen Literasi Sains Untuk Siswa SMP Kelas VII Semester II. Tesis Program Pascasarjana Universitas Negeri Padang. Padang: Tidak Diterbitkan.

[12]Plomp, Tjeerd dan Nienke Nieveen. 2013. Educational Design Research. Netherland: Netherlands Institute for Curriculum Development.

[13] Riduwan. 2009. Pengantar Statistika Sosial. Bandung: Alfabeta.

[14]Peraturan Akademik Universitas Negeri Padang 2015.

[15] Suci, Putri Islami dan Dwi Hilda Putri. 2019. Analysis of Needs for the Development of Microbiology Teaching Books Based on Science Technology Society (STM) on Microorganism Classification Materials for Padang University Biology Students. International Journals of Sciences and High Technologies, 15 (1), 86-90.

[16] Kapici, Hasan Ozgur, Hakan Akcay dan Robert E. Yager. 2017.Comparison of ScienceTechnology-Society Approach and Textbook Oriented Instruction on Student's Abilities to Apply Science Concepts. International Journal of Progressive Education, 13 (2), 18-28. 
[17] Sudjana, Nana. 2011. Dasar-dasar Proses Belajar Mengajar. Bandung: SinarBaruAlgesindo.

[18] Yalvac, B., Tekkaya, C., Cakiroglu, J., dan Kahyaoglu, E. 2009. Turkish Pre-Service Teacher's Views on Science-Technology-Society Issues. International Journal of Science Education, 29 (3), 331-348.

[19] Moore, V. J., Mc-Cullogh, A. C., dan Chessin, D.A. 2014. Societal Issue in Social Studies and Science Education: Promoting Responsible Citizenship. International Journal of Humanities and Social Science, 4 (10), 69-73.

[20] Pujriyanto. 2005. Desain Grafis Komputer (Teori Grafis Komputer). Yogyakarta: Andi.

[21] Nugroho, Eko. 2008. Pengenalan Teori Warna. Jakarta: Gramedia Pustaka.

[22] Sugiyono. 2012. Metode Penelitian Pendidikan: Pendekatan Kuantitatif, Kualitatif, dan R \& D. Bandung: Alfabeta.

[23] Lufri. 2007. Strategi Pembelajaran, Teori, Praktek dan Penelitian. Padang: UNP Press.

[24] Prastowo, Andi. 2013. Panduan Kreatif Membuat Buku ajar Inovatif: Menciptakan Metode Pembelajaran Yang Menarik Dan Menyenangkan. Jakarta: Kencana.

[25] Trianto. 2009. Mendesain Model Pembelajaran Inovatif: Konsep. Landasan dan Implementasinya pada Kurikulum Tingkat Satuan Pendidikan (KTSP). Jakarta: Kencana Prenada Media Group.

[26] Arikunto. 2013. Dasar-dasar Evaluasi Pendidikan. Jakarta: Bumi Aksara.

[27] Sukardi. 2011. Evaluasi Pendidikan Prinsip dan Operasionalnya. Jakarta: Bumi Aksara.

[28] Bauchspies, W. K., dan Jennifer C. 2006. Science, Technology, and Society A Sociological Approach. USA: Black Publishing.

[29] Nicholas, Maria. 2015. Student Knowledge: Curriculum, Assessment and Reporting. IBIMA, 14 (3), 1-16.

[30] Uno, H.B. 2008. Model Pembelajaran Menciptakan Proses Belajar Mengajar yang Kreatif dan Efektif. Jakarta: Bumi Aksara.

[31] Brookhat, S. M. 2004. Classroom Assessment: Tensions and Intersections in Theory and Practice. Teachers College Record, 106, 429458.

[32] Susilaningsih, E., K. Khotimah dan S. Nurhayati. 2018. Develompment of Performence Assessment Instrument Based Contextual Learning Measuring Students Laboratory Skills. Materials Science and Engineering. 349.

[33] Alkharusi, Hussain, Said Aldhafi, Hilal Alnabhani dan Muna Alkalbani. 2012. Educational Assessment Attitudes, Competence, Knowledge, and Practies: An Exploratury Study of Muscat Teachers in The Sultanate of Oman. Journal of Education and Learning, 1 (2), 217 232.

[34] Yani, Ahmad. 2014. Mindset Kurikulum 2013. Bandung: Alfabeta.

[35] Khan, Natalya N., Sholpan Zh, Kolumbayeva dan Raissa K. Karsybayena. 2016. Evaluation of The Program Effevtiveness of Research Competence Development in Prespective Elementary School Teachers. International Journal of Enviromental \& Science Education, 11 (18), 12299-12316. 